Family Medicine and Community Health

\section{Clinicopathological characteristics of 8697 patients with COVID-19 in China: a meta-analysis}

To cite: Zhu J, Zhong Z, Ji P, et al. Clinicopathological characteristics of 8697 patients with COVID-19 in China: a metaanalysis. Fam Med Com Health 2020;8:e000406. doi:10.1136/ fmch-2020-000406

\section{Check for updates}

(C) Author(s) (or their employer(s)) 2020. Re-use permitted under CC BY-NC. No commercial re-use. See rights and permissions. Published by BMJ.

Department of Emergency Medicine, The Second Affiliated Hospital of Guangxi Medical University, Nanning, Guangxi, China

Correspondence to Prof. Jianfeng Zhang; zhangjianfeng@stu.gxmu.edu.cn

Dr. Chunling Zhao; chunlingzha02018@163.com

\section{ABSTRACT}

Objective Our study aims to present a summary of the clinicopathological characteristics of patients affected by the coronavirus disease 2019 (COVID-19) that can be used as a reference for further research and clinical decisions.

Design Studies were included in the meta-analysis if they had cohort, case-control or case series designs and provided sufficient details on clinical symptoms, laboratory outcomes and asymptomatic patients.

Setting PubMed, Embase, Chinese Biomedical Literature Database, Wanfang, China Science and Technology Journal Database and China National Knowledge Infrastructure databases were electronically searched to identify related studies published between 1 January 2020 and 16 March 2020. Three reviewers independently examined the literature, extracted relevant data and assessed the risk of publication bias before including the studies in the metaanalysis.

Participants The confirmed cases of COVID-19. Results A total of 55 unique retrospective studies involving 8697 patients with COVID-19 were identified. Meta-analysis showed that a higher proportion of infected patients were male (53.3\%), and the two major symptoms observed were fever (78.4\%) and cough (58.3\%). Other common symptoms included fatigue (34\%), myalgia (21.9\%), expectoration (23.7\%), anorexia (22.9\%), chest tightness (22.9\%) and dyspnoea (20.6\%). Minor symptoms included nausea and vomiting $(6.6 \%)$, diarrhoea $(8.2 \%)$, headache (11.3\%), pharyngalgia (11.6\%), shivering $(15.2 \%)$ and rhinorrhea $(7.3 \%)$. About $5.4 \%$ of the patients were asymptomatic. Most patients showed normal leucocyte counts $(64.7 \%)$ and elevated $\mathrm{C}$ reactive protein levels (65.9\%). Lymphopaenia was observed in about $47.6 \%$ of the infected patients, along with abnormal levels of myocardial enzymes (49.4\%) and liver function (26.4\%). Other findings included leucopenia (23.5\%), elevated D-dimer (20.4\%), elevated erythrocyte sedimentation rate $(20.4 \%)$, leucocytosis $(9.9 \%)$, elevated procalcitonin (16.7\%) and abnormal renal function (10.9\%).

Conclusions The most commonly experienced symptoms of patients with COVID-19 were fever and cough. Myalgia, anorexia, chest tightness and dyspnoea were found in some patients. A relatively small percentage of patients were asymptomatic and could act as carriers of the disease. Most patients showed normal leucocyte counts, elevated levels of $\mathrm{C}$ reactive protein and lymphopaenia, confirming the viral origin of the disease.

\section{INTRODUCTION}

In the spring of 2020, the coronavirus disease 2019 (COVID-19) pandemic has spread to more than 200 countries around the world. ${ }^{2}$ As of 27 March 2020, the total number of confirmed cases has exceeded $500000 .^{3}$ This pandemic has become a serious threat to global health and continues to challenge healthcare systems worldwide. It was determined to be caused by a novel coronavirus, the severe acute respiratory syndrome coronavirus 2. ${ }^{4}$ Therefore, it is critical to understand and identify the key clinical and laboratory characteristics of patients with COVID-19 in order to help in early detection and isolation of infected individuals, as well as minimise the spread of the disease. ${ }^{5}$

Although a number of studies have attempted to explore this subject, most of them were single-centre studies that were conducted in a specific hospital or region. Due to differences in study design and small samples, the clinical symptoms, laboratory findings and other key outcomes of these studies are complicated and unclear. $^{6-8}$ For example, two recent systematic reviews ${ }^{910}$ of studies of patients with COVID-19 indicated a high incidence of fever $(>88 \%)$ and cough $(>68 \%)$, but only one ${ }^{10}$ reported symptoms of myalgia or fatigue $(35.8 \%)$. Both reviews meta-analysed small samples pooled from 10 studies.

Therefore, the present meta-analysis was performed to provide the most extensive, up-to-date description so far of clinicopathological characteristics of patients with COVID-19 and to provide a reference for clinical decisions and future research.

\section{MATERIALS AND METHODS}

Search strategy and study eligibility

This meta-analysis was carried out based on the guidelines of the Preferred Reporting 


\section{Box 1 Search strings used for the PubMed database}

\# 1 Corona virus [Title/Abstract]

\# 2 Coronavirus [Title/Abstract]

\# 3 2019-nCoV [Title/Abstract]

\# 4 COVID-19 [Title/Abstract]

\# 5 SARS-CoV-2 [Title/Abstract]

\# 6 \# 1 OR \# 2 OR \# 3 OR \# 4 OR \# 5

Items for Meta-Analyses of Observational Studies in Epidemiology Statement. ${ }^{11}$ We systematically examined the studies on clinicopathological characteristics of patients with COVID-19 indexed in the PubMed, Embase, Chinese Biomedical Literature, Wanfang, China Science and Technology Journal Database and China National Knowledge Infrastructure databases between 1 January 2020 and 16 March 2020. All references cited in these studies were also analysed manually to ensure that eligible papers were not overlooked. If multiple studies analysed the same patient population, we included only the one with more detailed information or the one published more recently. No language restrictions were incorporated during the literature search, and only literature published online was included. The following keywords were used, both separately and in combination, as part of the search strategy in each database: 'Corona virus', 'Coronavirus', '2019-nCoV', 'COVID-19' or 'SARS-CoV-2' (box 1).

Studies were included in the meta-analysis if they had cohort, case-control or case series designs and provided sufficient details on clinical symptoms, laboratory outcomes and asymptomatic patients. Only studies of more than 40 patients were included.

\section{Data extraction and quality assessment}

The literature selected was independently assessed by three reviewers based on the eligibility criteria, and relevant data were extracted. Disagreements were resolved by consensus. The titles and abstracts were first screened to identify the eligible articles, followed by a full-text review to obtain detailed information. When required, the authors were contacted directly to obtain further information and clarifications regarding their study. The following data were extracted from each included study: surname of first author; date of publication; study design; number, age and sex of patients; clinical and laboratory outcomes; and data relevant for assessing publication bias. The quality of observational case series was independently evaluated by the three reviewers based on the British National Institute for Clinical Excellence ${ }^{12}$ guidelines. This evaluation was conducted based on a set of eight criteria, and studies with a score greater than 4 were considered to be of high quality (total score $=8$ ).

\section{Statistical analyses}

All statistical analyses were performed using STATA V.12. Original incidence rates $r$ were transformed by the double arcsine method to ensure a normal distribution, and the

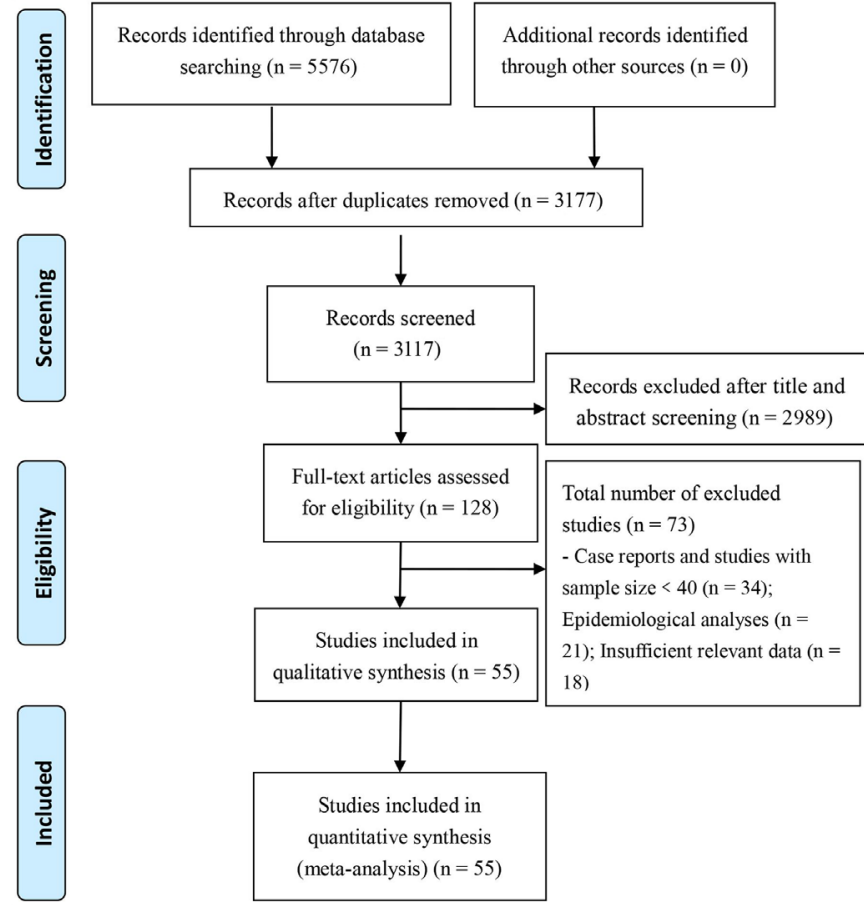

Figure 1 Flow chart depicting literature screening process.

resulting transformed rate $t r$ was used in single-arm metaanalysis. The heterogeneity between studies was analysed using a $\chi^{2}$ test $(\mathrm{p}<0.10)$ and quantified using the $\mathrm{I}^{2}$ statistic. When no statistical heterogeneity was observed, a fixed-effects model was used. Otherwise, potential sources of clinical heterogeneity were identified using subgroup and sensitivity analyses; these sources were eliminated, and the meta-analysis was repeated using a random-effects model. Pooled incidence rates $R$ were back-calculated from transformed rates $t r$ using the $R=[\sin (t r / 2)] .^{2} \mathrm{~A}$ two-tailed $\mathrm{p}<0.05$ was considered statistically significant. Publication bias was evaluated using a funnel plot along with Egger's regression test and Begg's test.

\section{RESULTS}

\section{Literature screening and assessment}

A total of 5576 records were identified from the various databases examined. After a detailed assessment based on the inclusion criteria, 55 unique studies ${ }^{6-813-64}$ involving 8697 patients with COVID-19 were included in the metaanalysis (figure 1).

\section{Characteristics of included studies}

All studies included in the meta-analysis were conducted in China and published between 6 February 2020 and 16 March 2020. These retrospective studies examined Chinese patients distributed across 31 provinces. A large proportion of these studies $(n=40)$ were based on data collected from a single centre, with no clear explanation regarding eligibility criteria. Follow-up data were reported for most patients. All studies received quality scores of 5-8, indicating high quality (table 1 ). 


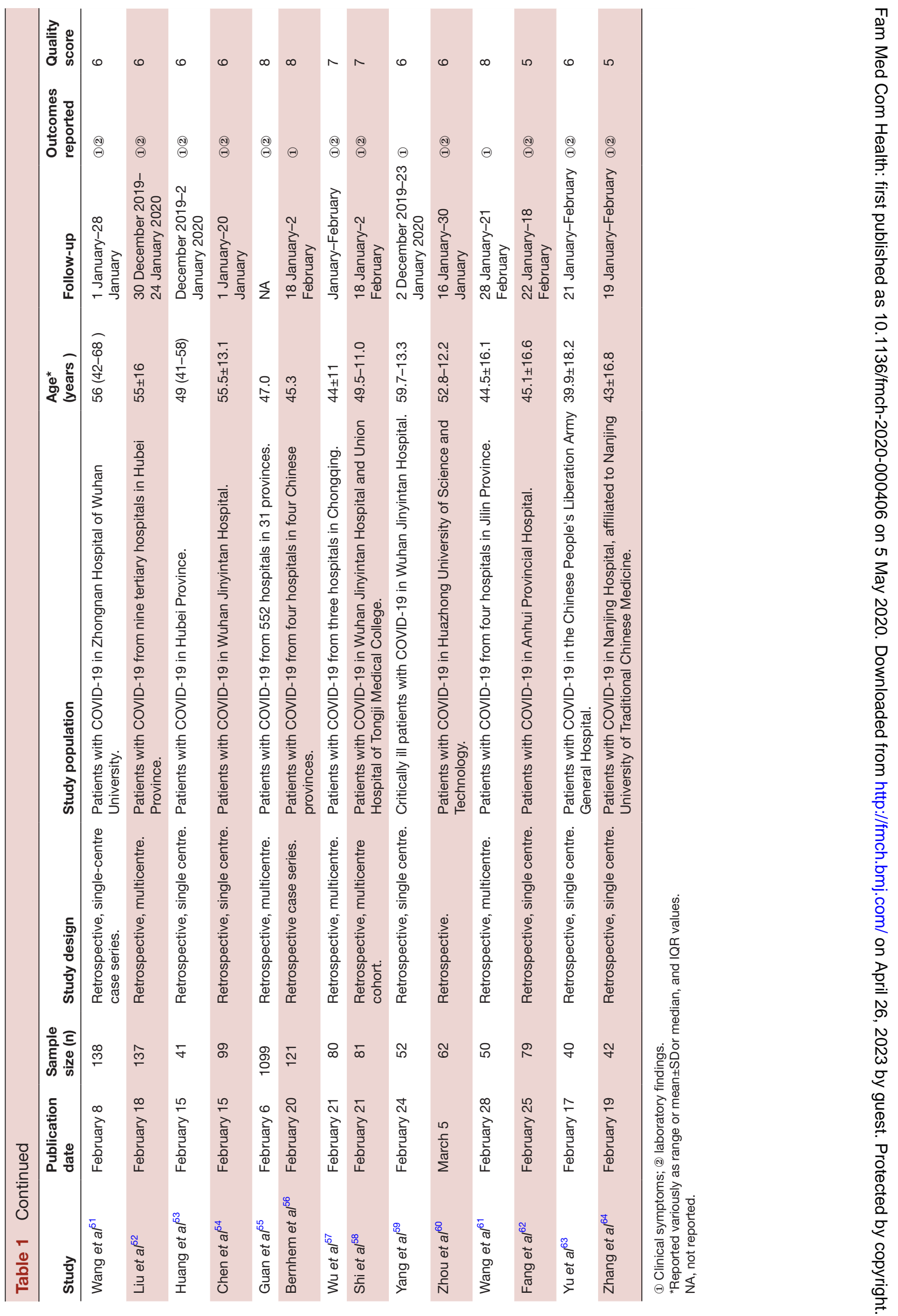


Table 2 Clinical symptoms observed in patients with COVID-19

\begin{tabular}{|c|c|c|c|c|c|c|c|}
\hline \multirow[b]{2}{*}{ Symptom } & \multirow[b]{2}{*}{ No. of studies } & \multirow[b]{2}{*}{ No. of patients } & \multicolumn{2}{|c|}{ Heterogeneity } & \multirow[b]{2}{*}{ Model } & \multicolumn{2}{|l|}{ Meta-analysis } \\
\hline & & & P value & $I^{2}(\%)$ & & R $(95 \% \mathrm{Cl})$ & $P$ value \\
\hline Fever & 51 & 8473 & $<0.001$ & 95.9 & Random & $0.784(0.736$ to 0.828$)$ & $<0.001$ \\
\hline Fatigue & 45 & 7848 & $<0.001$ & 96.9 & Random & $0.340(0.277$ to 0.405$)$ & $<0.001$ \\
\hline Myalgia & 37 & 5625 & $<0.001$ & 93.0 & Random & $0.219(0.177$ to 0.264$)$ & $<0.001$ \\
\hline Expectoration & 33 & 6408 & $<0.001$ & 95.8 & Random & 0.237 (0.185 to 0.294$)$ & $<0.001$ \\
\hline Dyspnoea & 25 & 3670 & $<0.001$ & 87.5 & Random & 0.206 (0.133 to 0.290$)$ & $<0.001$ \\
\hline Chest tightness & 30 & 5773 & $<0.001$ & 97.2 & Random & 0.229 (0.163 to 0.304$)$ & $<0.001$ \\
\hline Nausea and vomiting & 24 & 4941 & $<0.001$ & 82.2 & Random & 0.066 (0.048 to 0.086$)$ & $<0.001$ \\
\hline Shivering & 16 & 4394 & $<0.001$ & 96.8 & Random & 0.152 (0.090 to 0.228$)$ & $<0.001$ \\
\hline Asymptomatic & 10 & 878 & 0.002 & 66.3 & Random & $0.054(0.031$ to 0.084$)$ & $<0.001$ \\
\hline
\end{tabular}

\section{Meta-analysis results}

Gender distribution

Relevant data regarding the clinicopathological characteristics of 8697 patients with COVID-19 was collected. ${ }^{6-813-64}$ Significant heterogeneity was observed across all included studies $\left(\mathrm{I}^{2}=93.7 \%\right)$, therefore, a random-effects model was used in the meta-analysis. We found that $53.3 \%$ (95\% CI 50.3 to 56.4 ) of the patients were male.

\section{Clinical symptoms}

Two major symptoms, including fever $(78.4 \%)$ and cough $(58.3 \%)$, were highly prevalent among patients. Fatigue
$(34 \%)$, myalgia $(21.9 \%)$, expectoration $(23.7 \%)$, anorexia $(22.9 \%)$, chest tightness $(22.9 \%)$ and dyspnoea $(20.6 \%)$ also occurred frequently. Less frequent symptoms were nausea and vomiting $(6.6 \%)$, diarrhoea $(8.2 \%)$, headache $(11.3 \%)$, pharyngalgia $(11.6 \%)$, shivering $(15.2 \%)$ and rhinorrhea $(7.3 \%)$. Only $5.4 \%$ of patients with COVID-19 were found to be asymptomatic (table 2).

Pathological characteristics

A large proportion of patients had normal leucocyte counts $(64.7 \%)$ and high levels of $\mathrm{C}$ reactive protein $(65.9 \%)$ (figures 2 and 3 ). Lymphopaenia was observed

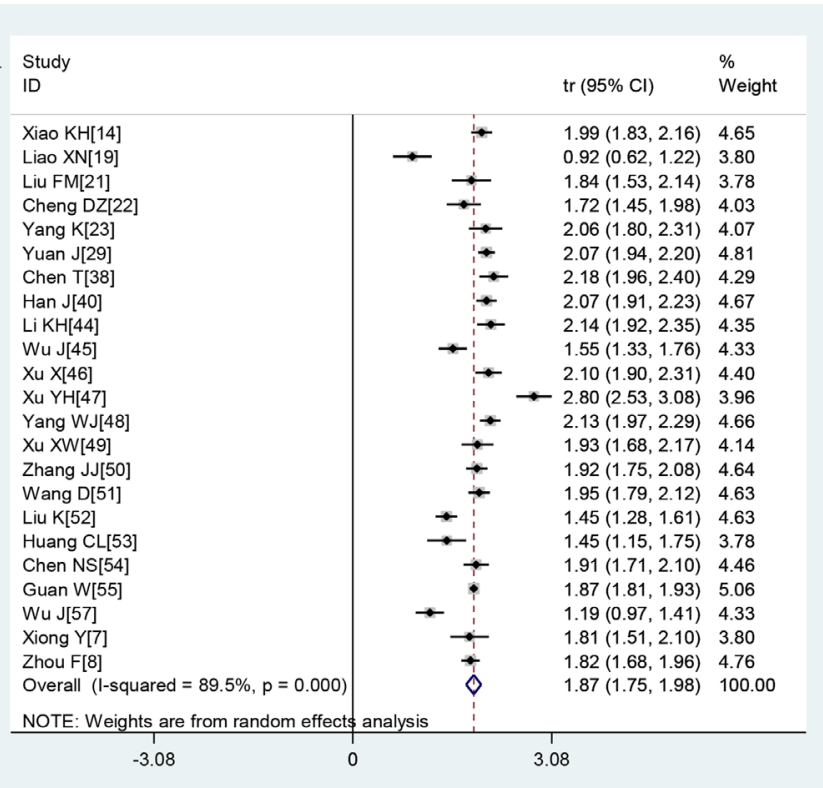

Figure 2 Transformed incidence rate of normal leucocyte count in patients with COVID-19.

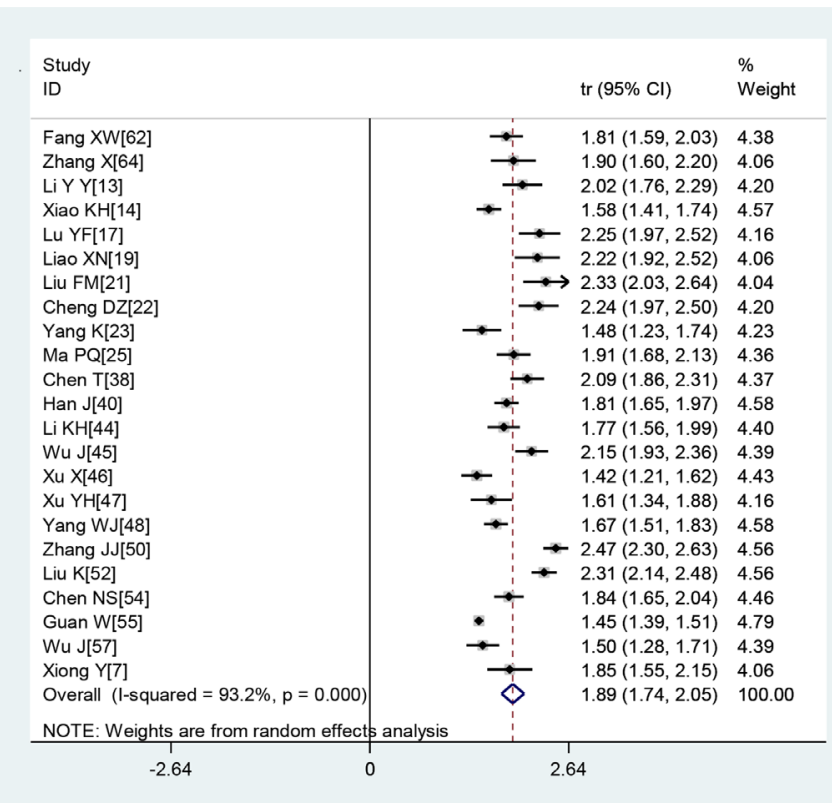

Figure 3 Transformed incidence rate of high $\mathrm{C}$ reactive protein levels in patients with COVID-19. 
Table 3 Pathological characteristics of patients with COVID-19

\begin{tabular}{|c|c|c|c|c|c|c|c|}
\hline \multirow[b]{2}{*}{ Characteristic } & \multirow{2}{*}{$\begin{array}{l}\text { No. of } \\
\text { studies }\end{array}$} & \multirow{2}{*}{$\begin{array}{l}\text { No. of } \\
\text { patients }\end{array}$} & \multicolumn{2}{|c|}{ Heterogeneity } & \multirow[b]{2}{*}{ Model } & \multicolumn{2}{|l|}{ Meta-analysis } \\
\hline & & & $P$ value & $I^{2}(\%)$ & & $\mathrm{R}(95 \% \mathrm{CI})$ & $P$ value \\
\hline Leucocytosis & 21 & 3936 & $<0.001$ & 90.6 & Random & 0.099 (0.069 to 0.134$)$ & $<0.001$ \\
\hline Normal leucocyte count & 23 & 3267 & $<0.001$ & 89.5 & Random & 0.647 (0.591 to 0.700$)$ & $<0.001$ \\
\hline Leucopenia & 27 & 4233 & $<0.001$ & 89.6 & Random & 0.235 (0.194 to 0.279$)$ & $<0.001$ \\
\hline Lymphopaenia & 32 & 4660 & $<0.001$ & 94.4 & Random & 0.476 (0.413 to 0.540$)$ & $<0.001$ \\
\hline High $\mathrm{C}$ reactive protein & 23 & 2912 & $<0.001$ & 93.2 & Random & 0.659 (0.586 to 0.728$)$ & $<0.001$ \\
\hline High procalcitonin & 13 & 2190 & $<0.001$ & 96.6 & Random & 0.167 (0.083 to 0.274$)$ & $<0.001$ \\
\hline High D-dimer & 9 & 2354 & $<0.001$ & 90.4 & Random & 0.204 (0.147 to 0.267$)$ & $<0.001$ \\
\hline $\begin{array}{l}\text { High erythrocyte sedimentation } \\
\text { rate }\end{array}$ & 7 & 455 & $<0.001$ & 90.4 & Random & 0.204 (0.147 to 0.267$)$ & $<0.001$ \\
\hline Abnormal liver function & 11 & 2524 & $<0.001$ & 90.1 & Random & 0.264 (0.204 to 0.329$)$ & $<0.001$ \\
\hline Abnormal renal function & 8 & 2183 & $<0.001$ & 96.1 & Random & 0.109 (0.045 to 0.196$)$ & $<0.001$ \\
\hline High myocardial enzymes & 11 & 2541 & $<0.001$ & 96.1 & Random & 0.494 (0.264 to 0.725$)$ & $<0.001$ \\
\hline
\end{tabular}

in many patients $(47.6 \%)$, along with elevated levels of myocardial enzymes $(49.4 \%)$ and abnormal liver function $(26.4 \%)$. Also observed were leucopenia (23.5\%), leucocytosis (9.9\%), abnormal renal function (10.9\%), elevated levels of D-dimer (20.4\%), elevated erythrocyte sedimentation rate $(20.4 \%)$ and elevated procalcitonin $(16.7 \%)$ (table 3$)$.

\section{Subgroup analysis}

Patients were stratified into two groups based on the date of initial diagnosis: group 1 included all patients and group 2 included those diagnosed between December 2019 and 31 January 2020 (table 4). We found that all patients diagnosed before 31 January had higher incidence rates of fever and cough. No significant difference was observed in the heterogeneity between the subgroups and the overall heterogeneity, indicating that the date of initial diagnosis was not the main source of heterogeneity.

Sensitivity analysis

A sensitivity analysis was carried out by excluding one study at a time and reanalysing the entire dataset. We found that the pooled incidence rates did not change substantially, indicating the reliability and stability of our meta-analysis (eg, figure 4).

\section{Evaluation of publication bias}

The $\mathrm{p}$ values derived using the Egger's and the Begg's test for all the clinicopathological characteristics showed no obvious publication bias (table 5). A funnel plot based on the incidence rate of fever showed $p$ values of 0.091

Table 4 Analysis of clinical symptoms observed in patients with COVID-19, stratified by date of initial diagnosis*

\begin{tabular}{|c|c|c|c|c|c|c|c|}
\hline \multirow[b]{2}{*}{ Clinical symptom } & \multirow[b]{2}{*}{ No. of studies } & \multirow[b]{2}{*}{ No. of patients } & \multicolumn{2}{|c|}{ Heterogeneity } & \multirow[b]{2}{*}{ Model } & \multicolumn{2}{|l|}{ Meta-analysis } \\
\hline & & & $P$ value & $I^{2}(\%)$ & & R $(95 \% \mathrm{Cl})$ & $P$ value \\
\hline \multicolumn{8}{|l|}{ Fever } \\
\hline Group 1 & 51 & 8473 & $<0.001$ & 95.9 & Random & 0.784 (0.736 to 0.828$)$ & $<0.001$ \\
\hline Group 2 & 14 & 2162 & $<0.001$ & 97.9 & Random & 0.813 (0.667 to 0.924$)$ & $<0.001$ \\
\hline \multicolumn{8}{|l|}{ Fatigue } \\
\hline Group 1 & 45 & 7848 & $<0.001$ & 96.9 & Random & 0.340 (0.277 to 0.405$)$ & $<0.001$ \\
\hline Group 2 & 11 & 1971 & $<0.001$ & 93.9 & Random & 0.366 (0.268 to 0.470$)$ & $<0.001$ \\
\hline Cough & & & & & & & $<0.001$ \\
\hline Group 1 & 52 & 8539 & $<0.001$ & 97.2 & Random & 0.583 (0.515 to 0.649 ) & $<0.001$ \\
\hline Group 2 & 14 & 2162 & $<0.001$ & 86.6 & Random & 0.640 (0.574 to 0.703$)$ & $<0.001$ \\
\hline Myalgia & & & & & & & $<0.001$ \\
\hline Group 1 & 37 & 5625 & $<0.001$ & 93.0 & Random & 0.219 (0.177 to 0.264$)$ & $<0.001$ \\
\hline Group 2 & 10 & 1938 & $<0.001$ & 91.7 & Random & $0.271(0.193$ to 0.358$)$ & $<0.001$ \\
\hline
\end{tabular}

*Group 1: all patients; group 2: diagnosed before 31 January 2020. 
Meta-analysis estimates, given named study is omitted

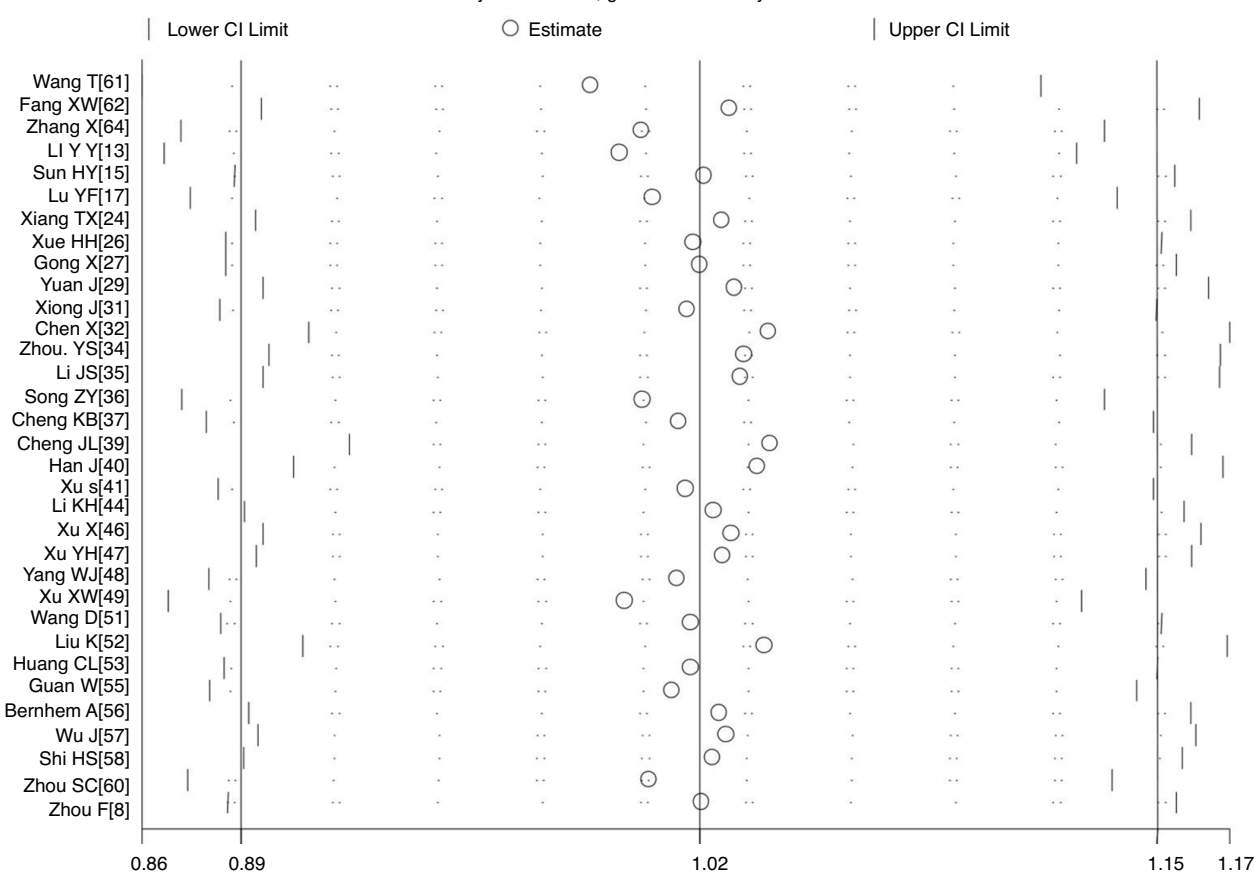

Figure 4 Sensitivity analysis of the incidence rate of expectoration in patients with COVID-19.

in Egger's test and 0.703 in Begg's test (figure 5). These results confirm that there is no publication bias.

\section{DISCUSSION}

In this meta-analysis, we examined 55 independent studies $^{6-8}$ 13-64 reporting clinicopathological data on 8697 patients with COVID-19 distributed across 31 provinces in China. The studies included in this analysis comprise the latest research available on COVID-19 through 16 March 2020. Our results indicate that there is a slightly higher proportion of male patients $(53.3 \%)$ and that the main symptoms of this disease are fever $(78.4 \%)$, cough $(58.3 \%)$ and fatigue $(34 \%)$. Compared with previous results, ${ }^{910}$ our findings reveal lower incidence rates of the two major symptoms of this disease, which we found to depend to some extent on whether diagnosis was made before or after 31 January 2020, reflecting with the progress of the epidemic, the number of atypical manifestations has growed gradually. For example, some patients developed gastrointestinal symptoms, such as diarrhoea, nausea and vomiting. These results highlight the importance of also taking into account non-respiratory symptoms of the disease.

Most patients with COVID-19 showed normal leucocyte counts and lymphopqenia. Few patients had leucocytosis and elevated procalcitonin levels, confirming that this

Table 5 Evaluation of publication bias using the Egger's and the Begg's test

\begin{tabular}{llllcc}
\hline Characteristic & P (Egger's) & P (Begg's) & Characteristic & P (Egger's) & P (Begg's) \\
\hline Fever & 0.091 & 0.703 & Shivering & 0.642 & 0.137 \\
Cough & 0.259 & 0.776 & Asymptomatic & 0.840 & 0.589 \\
Fatigue & 0.094 & 0.018 & Leucocytosis & 0.087 & 0.238 \\
Myalgia & $<0.001$ & $<0.001$ & Normal leucocyte count & 0.760 & 0.195 \\
Headache & 0.034 & 0.015 & Leucopenia & 0.790 \\
Diarrhoea & 0.001 & 0.004 & Lymphopenia & 0.062 & 0.910 \\
Expectoration & 0.208 & 0.018 & High C reactive protein & 0.001 \\
Dyspnoea & 0.386 & 0.088 & High procalcitonin & 0.138 \\
Chest tightness & 0.234 & 0.164 & High D-dimer & 0.022 \\
Nausea and vomiting & 0.102 & 0.092 & High erythrocyte sedimentation rate & 0.222 \\
Pharyngalgia & 0.089 & 0.086 & Abnormal liver function & 0.363 & 0.466 \\
Rhinorrhea & 0.748 & 0.059 & Abnormal renal function & 0.050 \\
Anorexia & 0.002 & 0.006 & High myocardial enzymes & 0.048 \\
\hline
\end{tabular}


Begg's funnel plot with pseudo $95 \%$ confidence limits

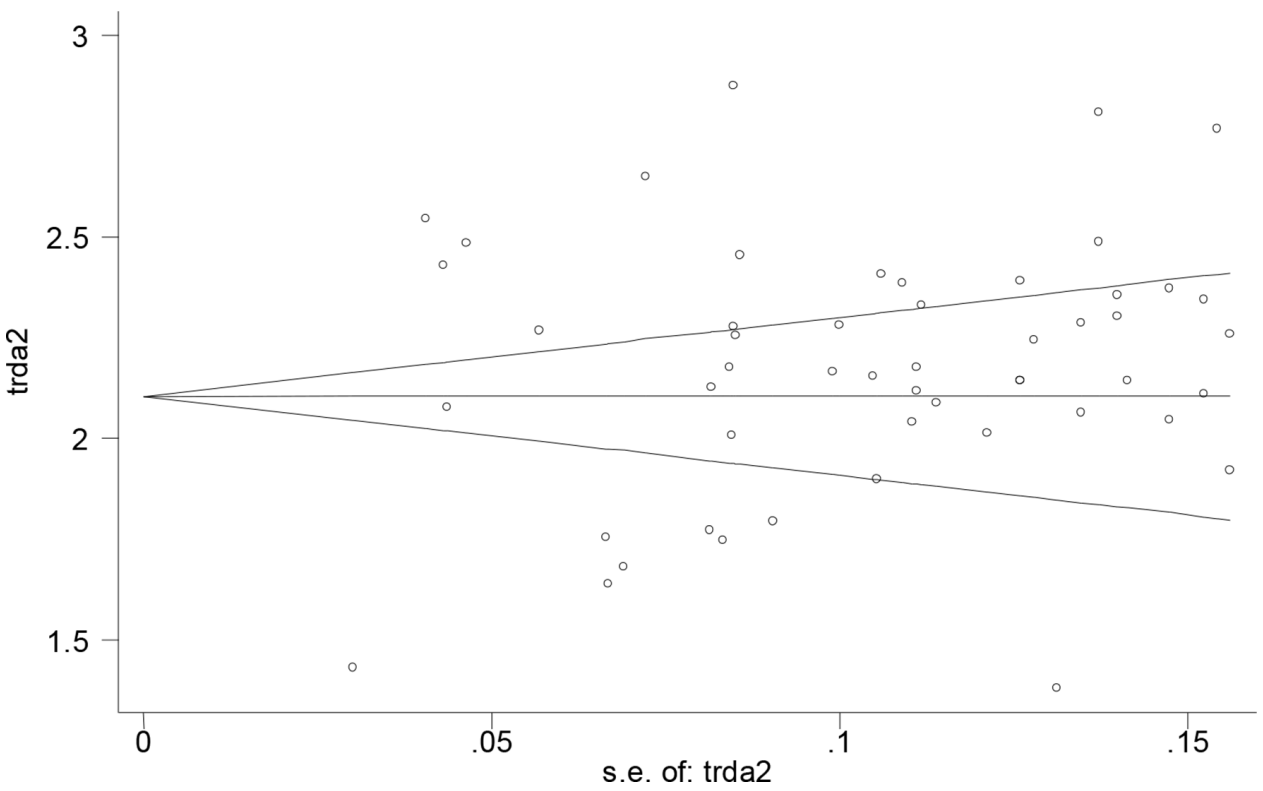

Figure 5 Evaluation of publication bias using a funnel plot based on the incidence rate of fever.

disease is transmitted by a virus. Therefore, it is essential for clinicians to use such pathological findings to rule out the presence of bacterial infections. In this study, $49.4 \%$ of the patients presented with myocardial enzyme spectrum abnormalities, which manifested as an increase in lactate dehydrogenase levels. Studies have shown that elevated levels of lactate dehydrogenase can be a risk factor for rapid progression from mild to critical COVID19. ${ }^{65}$ Therefore, monitoring the function of important organs during treatment is critical, and treatment should be adjusted as needed to preserve and maintain organ function.

Infected people who are asymptomatic can act as a source of infection, ${ }^{66}$ especially since the estimated median incubation period is 5-6 days (range 0-14 days). An analysis by the Chinese Center for Disease Control and Prevention conducted through 17 February 2020 suggested that the proportion of asymptomatic patients was only around $1 \%,{ }^{67}$ but our results suggest that the proportion is closer to $5 \%$. This increase may reflect the growing experience of hospitals with this novel disease and increasing screening of suspected COVID-19 cases for viral infection, allowing the correct diagnosis of greater proportions of patients showing no or less typical manifestations. Therefore, to control the spread of this disease, general practitioners should carefully monitor individuals with histories of contact in areas where outbreaks have occurred or who had contact with suspected or confirmed cases of COVID-19 within 14 days before onset of symptoms. ${ }^{68}$ Epidemiological history of patients should be investigated in detail, and asymptomatic infected people in the community should be identified as quickly as possible to control spread of the disease.

A recent study suggests that, considering different scenarios, highly effective contact tracing and case isolation are sufficient to control a new outbreak of COVID-19 within 3 months. ${ }^{69}$ Therefore, isolation, quarantine, social distancing, and community containment measures should be rapidly implemented in high-risk countries or regions. ${ }^{70}$ In China, community engagement has been the first line of defence in the battle against the COVID-19 pandemic. General practitioners act as both gatekeepers and health promoters by educating the public and guiding the community in the fight against this disease. ${ }^{71}$ Monitoring people at designated checkpoints, intercepting transmission routes in a timely manner and preventing local outbreaks are critical to prevent repeat epidemics. $^{72}$

Although this study rigorously analysed clinical and laboratory data collected from a large sample of patients with COVID-19, we were unable to eliminate the significant heterogeneity observed between studies. For example, the course and the severity of the disease varied across studies. Given that most of the studies included in our meta-analysis were single-centre, retrospective studies, it was difficult for us to control for the effects of several confounding factors, including bias in patient admission and selection, as well as differences in disease severity and course. Further research is required to verify and extend our results for China. Continued surveillance across multiple countries, along with transparent and accurate reporting of patient characteristics and testing policies, will help us gain a better understanding of this global pandemic. $^{73}$

\section{CONCLUSION}

In summary, Current evidence showed that the most commonly experienced symptoms of patients with COVID-19 were fever and cough. Myalgia, anorexia, 
chest tightness and dyspnoea were found in some patients. A relatively small percentage of patients were asymptomatic and could act as carriers of the disease. Most patients showed normal leucocyte counts, elevated levels of $\mathrm{C}$ reactive protein and lymphopenia, confirming the viral origin of the disease. Due to limited quality and quantity of the included studies, more highquality prospective studies are required to verify above conclusions.

Correction notice This article has been corrected since it was published Online First. The article type has been modified from 'Original research' to 'Review'.

Contributors PJ, JP and BL collected and analysed the data. HL helped collect the data. JZ acquired the funding. JZ designed the study, and wrote the first draft of the manuscript. CZ and JZ designed and supervised the study, and finalised the manuscript, which all authors read and approved.

Funding This study was supported by grants from the National Natural Science Foundation of China (81960343); the Emergency Science and Technology Brainstorm Project for the Prevention and Control of COVID-19, which is part of the Guangxi Key Research and Development Plan (2020AB39028).

Competing interests None declared.

Patient consent for publication Not required.

Provenance and peer review Not commissioned; externally peer reviewed.

Data availability statement Data are available on reasonable request.

Open access This is an open access article distributed in accordance with the Creative Commons Attribution Non Commercial (CC BY-NC 4.0) license, which permits others to distribute, remix, adapt, build upon this work non-commercially, and license their derivative works on different terms, provided the original work is properly cited, appropriate credit is given, any changes made indicated, and the use is non-commercial. See: http://creativecommons.org/licenses/by-nc/4.0/.

\section{REFERENCES}

1 WHO. Who Director-General's opening remarks at the media briefing on COVID-19 -11. Available: https://www.who.int/dg/speeches/ detail/who-director-general-s-opening-remarks-at-the-mediabriefing-on-covid-19-11-march-2020 [Accessed 29 Mar 2020].

2 WHO. Coronavirus disease(COVID-19) outbreak situation. Available: https://www.who.int/emergencies/diseases/novel-coronavirus-2019 [Accessed 29 Mar 2020].

3 WHO. Coronavirus disease 2019 (COVID-19)Situation Report-67). Available: https://www.who.int/docs/default-source/coronaviruse/ situation-reports/20200327-sitrep-67-covid-19.pdf?sfvrsn= b65f68eb_4 [Accessed 29 Mar 2020].

4 WHO. Naming the coronavirus disease (COVID-19) and the virus that causes it. Available: https://www.who.int/emergencies/diseases/ novel-coronavirus-2019/technical-guidance/naming-the-coronavirusdisease-(covid-2019)-and-the-virus-that-causes-it [Accessed 29 Mar 2020].

5 Zhang MQ, Wang XH, Chen YL, et al. [Clinical features of 2019 novel coronavirus pneumonia in the early stage from a fever clinic in Beijing]. Zhonghua Jie He He Hu Xi Za Zhi 2020;43:E013.

6 Zhao W, Zhong Z, Xie X, et al. Relation between chest CT findings and clinical conditions of coronavirus disease (COVID-19) pneumonia: a multicenter study. AJR Am J Roentgenol 2020:1-6.

7 Xiong Y, Sun D, Liu Y, et al. Clinical and high-resolution CT features of the COVID-19 infection: comparison of the initial and follow-up changes. Invest Radiol 2020. doi:10.1097/RLI.0000000000000674. [Epub ahead of print: 03 Mar 2020].

8 Zhou F, Yu T, Du R, et al. Clinical course and risk factors for mortality of adult inpatients with COVID-19 in Wuhan, China: a retrospective cohort study. Lancet 2020;395:1054-62.

9 Sun P, Qie S, Liu Z, et al. Clinical characteristics of 50466 hospitalized patients with2019-nCoV infection. J Med Virol 2020.

10 LQ L, Huang T, Wang YQ, et al. COVID-19 patients' clinical characteristics, discharge rate, and fatality rate of meta-analysis. $J$ Med Virol 2020.

11 Stroup DF, Berlin JA, Morton SC, et al. Meta-Analysis of observational studies in epidemiology: a proposal for reporting. meta-analysis of observational studies in epidemiology (moose) group. JAMA 2000;283:2008-12.
12 NICE. Appendix 4: quality of case series. Available: https://www.nice org.uk/guidance/cg3/documents/appendix-4-quality-of-case-seriesform2 [Accessed 29 Mar 2020]

13 Li YY, Wang WN, Lei Y, et al. [Comparison of the clinical characteristics between RNA positive and negative patients clinically diagnosed with 2019 novel coronavirus pneumonia]. Zhonghua Jie He He Hu Xi Za Zhi 2020;43:E023.

14 Xiao KF, Shui LL, Pang XH, et al. The clinical features of the 143 patients withCOVID-19 in north-east of Chongqing. Journal of Third Military Medical University 2020.

15 Sun HY, YF B, Zhu ZG, et al. A preliminary study on TCM syndrome characteristics of 88 patients with COVID-19 in Tianjin. J Tradit Chin Med 2020.

16 Xu B, Fan CY, Zou YL, et al. Analysis of traditional Chinese medicine syndromes of 46 cases of COVID-19. Chinese journal of experimental traditional medical formulae 2020.

17 YF L, Yang ZG, Wang M. Analysis on Chinese medical clinical characteristics of 50 patients with 2019-nCoV-infected pneumonia. Academic Journal of Shanghai University of traditional Chinese medicine, 2020.

18 Wang J, Liu JP, Wang YY, et al. [Dynamic Changes of Chest CT Imaging in Patients With Corona Virus disease-19 (COVID-19)]. Zhejiang Da Xue Xue Bao Yi Xue Ban 2020;49.

19 Liao XN, Zhou J, Cao J, et al. Chest CT features comparison between COVID-19 and bacterial pneumonia. Medical Journal of Wuhan university 2020;26.

20 XT Y, Ye H, Yang SF, et al. Chest CT features of COVID-19. The Journal of Practical Medicine 2020.

21 Liu FM, Ding HL, Gong XM, et al. Chest CT performance and clinica characteristics of coronavirus disease 2019 (COVID-19). Radiologic Practice 2020.

22 Cheng DZ, Li Y. Clinical effectiveness and case analysis in $54 \mathrm{NCp}$ patients treated with lanhuaqingwen granules. World Chinese Medicine 2020

23 Yang K, Ren MH, Xiao YL, et al. Epidemiological and clinical characteristics of 57 casesof new coronavirus pneumonia in nonepidemic areas. J Third Mil Med Univ 2020.

24 Xiang TX, Liu JM, Xu F, et al. Analysis of clinical characteristics of 49 patientswith novel coronavirus pneumonia in Jiangxi Province. Chinese J Respir Crit Care Med 2020.

25 PQ M, Yuan YS, Zhang L, et al. Manifestations of the initial chest CT and its association with laboratory tests in 75 COVID-19 patients. Int $\checkmark$ Med Radiol 2020.

26 Xue $\mathrm{HH}$, Zhang HY, Pang ZH, et al. Analysis on TCM clinical characteristics of66 COVID-19 cases in the recover period. Shan $J$ Tradit Chin Med 2020

27 Gong X, Mou FZ, Wei DR, et al. The clinical characteristics and medication analysis of corona virus disease 2019. World Chinese Medicine 2020.

28 Ran J, YP L, QT L, et al. Study of TCM syndrome in 209 nove coronavirus pneumonia cases of Chongqing in 2020. Journal of Emergency in Traditional Chinese Medicine 2020.

29 Yuan J, Sun YL, Zuo YJ, et al. Clinical characteristics of 223 novel coronavirus pneumonia cases in Chongqing. Journal of Southwest University(Natural Science Edition) 2020.

30 Shi J, Yang ZG, Chen Y, et al. Clinical observation on 49 cases of non-critical coronavirus disease 2019 in Shanghai treated by integrated traditional Chinese and Western medicine. Shanghai Journal of Traditional Chinese Medicine 2020.

31 Xiong J, Jiang WL, Zhou Q, et al. Clinical characteristics, treatment, and prognosis in89 cases of COVID-2019. Medical Journal of Wuhan University(Health Sciences) 2020.

32 Chen X, Tong J, Xiang JH, et al. Retrospective study on the epidemiological characteristics of 139 patients with novel coronavirus pneumonia on the effects of severity. Chongqing Medicine 2020

33 Fang L, Zhu QG, Cheng W, et al. Retrospective analysis on 308 cases of COVID-19 and clinical application program of Kang Yi Qiang Shen Gong exercise prescription. Shanghai Journal of Traditional Chinese Medicine 2020.

34 Zhou SY, Wang CT, Zhang W, et al. Clinical characteristics and treatment effect of 537 cases of novel coronavirus pneumonia in Shandong Province. Journal of Shandong University(Health Sciences) 2020.

35 JS L, SY L, Xie Y, et al. Clinical characteristics and TCM syndrome distribution in 524 cases of novel coronavirus pneumonia in Henan. Journal of Traditional Chinese Medicine 2020.

36 Song ZY, Yong WX, Li J, et al. Analysis on TCM syndrome rules of 60 Casesof novel coronavirus pneumonia in Gansu area. Chinese Journal of Information on TCM 2020. 
37 Cheng KB, Wei M, Shen H, et al. Clinical characteristics of 463 patients with common and severe type coronavirus disease 2019. Shanghai Medical Journal 2020.

38 Chen T, Jiang ZY, Xu W, et al. Clinical features and CT imaging analysis of 76patiens with corona virus disease 2019. Journal of Jinan University 2020.

39 Cheng JL, Huang C, Zhang GJ, et al. [Epidemiological characteristics of novel coronavirus pneumonia in Henan]. Zhonghua Jie He He Hu Xi Za Zhi 2020;43:E027.

40 Han J, Dong XF, Hu F, et al. Clinical characteristics of 120 patients infected with SARS-CoV-2. Guangdong Medical Journal 2020.

$41 \mathrm{Xu} \mathrm{S}, \mathrm{HT} H, \mathrm{YG} \mathrm{H}$, et al. Clinical features of 62 cases of coronavirus disease 2019complicated with acute renal injury. Medical Journal of Wuhan University 2020:1-5.

42 Dong XC, Li JM, Bai JY, et al. [Epidemiological characteristics of confirmed COVID-19 cases in Tianjin]. Zhonghua Liu Xing Bing Xue Za Zhi 2020;41:638-42.

43 Sun WW, Ling F, Pan JR, et al. [Epidemiological characteristics of 2019 novel coronavirus family clustering in Zhejiang Province]. Zhonghua Yu Fang Yi Xue Za Zhi 2020;54:E027.

$44 \mathrm{Li} \mathrm{K}, \mathrm{Wu} \mathrm{J}$, Wu F, et al. The clinical and chest CT features associated with severe and critical COVID-19 pneumonia. Invest Radiol 2020;2020. doi:10.1097/RLI.0000000000000672. [Epub ahead of print: 29 Feb 2020].

$45 \mathrm{Wu}$ J, Liu J, Zhao X, et al. Clinical characteristics of imported cases of COVID-19 in Jiangsu Province: a multicenter descriptive study. Clin Infect Dis 2020. doi:10.1093/cid/ciaa199. [Epub ahead of print: 29 Feb 2020].

$46 \mathrm{Xu} \mathrm{X}, \mathrm{Yu} \mathrm{C}, \mathrm{Qu} \mathrm{J}$, et al. Imaging and clinical features of patients with 2019 novel coronavirus SARS-CoV-2. Eur J Nucl Med Mol Imaging 2020;47:1275-80.

$47 \mathrm{Xu}$ Y-H, Dong J-H, An W-M, et al. Clinical and computed tomographic imaging features of novel coronavirus pneumonia caused by SARS-CoV-2. J Infect 2020;80:394-400.

48 Yang W, Cao Q, Qin L, et al. Clinical characteristics and imaging manifestations of the 2019 novel coronavirus disease (COVID19):A multi-center study in Wenzhou city, Zhejiang, China. J Infect 2020;80:388-93.

$49 \mathrm{Xu} \mathrm{X-W,} \mathrm{Wu} \mathrm{X-X,} \mathrm{Jiang} \mathrm{X-G,} \mathrm{et} \mathrm{al.} \mathrm{Clinical} \mathrm{findings} \mathrm{in} \mathrm{a} \mathrm{group}$ of patients infected with the 2019 novel coronavirus (SARSCov-2) outside of Wuhan, China: retrospective case series. BMJ 2020;368:m606.

50 Zhang J-J, Dong X, Cao Y-Y, et al. Clinical characteristics of 140 patients infected with SARS-CoV-2 in Wuhan, China. Allergy 2020 doi:10.1111/all.14238. [Epub ahead of print: 19 Feb 2020].

51 Wang D, Hu B, Hu C, et al. Clinical characteristics of 138 hospitalized patients with 2019 novel coronavirus-infected pneumonia in Wuhan, China. JAMA 2020;323:1061.

52 Kui L, Fang YY, Deng Y, et al. Clinical characteristics of novel coronavirus cases in tertiary hospitals in Hubei Province. Chin Med $J$ 2020.

53 Huang C, Wang Y, Li X, et al. Clinical features of patients infected with 2019 novel coronavirus in Wuhan, China. Lancet 2020;395:497-506

54 Chen N, Zhou M, Dong X, et al. Epidemiological and clinical characteristics of 99 cases of 2019 novel coronavirus pneumonia in Wuhan, China: a descriptive study. Lancet 2020;395:507-13.

55 Guan WJ, ZY N, Hu Y, et al. Clinical characteristics of 2019 novel coronavirus infection in China. N Engl J Med 2020.

56 Bernheim A, Mei X, Huang M, et al. Chest CT findings in coronavirus Disease-19 (COVID-19): relationship to duration of infection. Radiology 2020:200463.
$57 \mathrm{Wu}$ J, Wu X, Zeng W. Chest CT findings in patients with coronavirus disease 2019 and its relationship with clinical features, 2020. Available: https://www-ncbi-nlm-nih-gov.library.westernwyoming. edu/pubmed/?term $=32091414$

58 Shi H, Han X, Jiang N, et al. Radiological findings from 81 patients with COVID-19 pneumonia in Wuhan, China: a descriptive study. Lancet Infect Dis 2020;20:425-34.

59 Yang X, Yu Y, Xu J, et al. Clinical course and outcomes of critically ill patients with SARS-CoV-2 pneumonia in Wuhan, China: a singlecentered, retrospective, observational study. Lancet Respir Med 2020. doi:10.1016/S2213-2600(20)30079-5. [Epub ahead of print: 24 Feb 2020].

60 Zhou S, Wang Y, Zhu T, et al. Ct features of coronavirus disease 2019 (COVID-19) pneumonia in 62 patients in Wuhan, China. AJR Am J Roentgenol 2020:1-8.

61 Wang T, Shi L, Chen YY, et al. Clinical efficacy analysis of 50 cases of corona virus disease 2019 in traditional Chinese medicine. Jilin Journal of Chinese Medicine 2020.

62 Fang XW, Mei Q, Yang TJ, et al. Clinical characteristics and treatment analysis of 79 cases of COVID-19. Chinese Pharmacological Bulletin 2020.

63 SM Y, Cui YF, Wang ZX, et al. Analysis of the relationship between clinical features and tongue manifestations of 40 cases with novel coronavirus pneumonia. Beijing Journal Of Traditional Chinese Medicine 2020.

64 Zhang X, Li L, Dai GC, et al. A preliminary study on the clinical characteristicsandchinese medical syndrome of 42 cases of COVID-19 in Nanjing. Journal of Nanjing University of Traditional Chinese Medicine 2020.

65 Phan LT, Nguyen TV, Luong QC, et al. Importation and human-tohuman transmission of a novel coronavirus in Vietnam. N Engl J Med 2020;382:872-4.

66 National Health Commission Office. The Guideline for the diagnosis and treatmentof novel coronavirus pneumonia (trial version sixth). Available: http://www.nhc.gov.cn/xcs/zhengcwj/202002/8334a832 6dd94d329df351d7da8aefc2/files/b218cfeb1bc54639af227f92 2bf6b817.pdf [Accessed 29 Mar 2020].

67 Strategy and Policy Working Group for NCIP Epidemic Response. [Urgent research agenda for the novel coronavirus epidemic: transmission and non-pharmaceutical mitigation strategies] Zhonghua Liu Xing Bing Xue Za Zhi 2020;41:1-6.

68 Razai MS, Doerholt K, Ladhani S, et al. Coronavirus disease 2019 (covid-19): a guide for UK GPs. BMJ 2020;368:m800.

69 Hellewell J, Abbott S, Gimma A, et al. Feasibility of controlling COVID-19 outbreaks by isolation of cases and contacts. Lancet Glob Health 2020;8:e488-96.

70 Hopman J, Allegranzi B, Mehtar S. Managing COVID-19 in low- and middle-income countries. JAMA 2020. doi:10.1001/jama.2020.4169. [Epub ahead of print: 16 Mar 2020].

71 Li DKT, Zhu S. Contributions and challenges of general practitioners in China fighting against the novel coronavirus crisis. Fam Med Community Health 2020;8:e000361.

72 ZB H, Song C. Discovery and management of novel coronavirus pneumonia infectedwith latent infection. Chinese Journal of Preventive Medicine 2020;54

73 Onder G, Rezza G, Brusaferro S. Case-Fatality rate and characteristics of patients dying in relation to COVID-19 in Italy. JAMA 2020. doi:10.1001/jama.2020.4683. [Epub ahead of print: 23 Mar 2020]. 
Correction: Clinicopathological characteristics of 8697

patients with COVID-19 in China: a meta-analysis

Zhu J, Zhong Z, Ji P, et al. Clinicopathological characteristics of 8697 patients with COVID-19 in China: a meta-analysis. Fam Med Com Health 2020;8:e000406. doi: 10.1136/ fmch-2020-000406

This article was published as an 'Original research' article when it should have been listed as a 'Review' article. This has now been updated in the online HTML and PDF.

Open access This is an open access article distributed in accordance with the Creative Commons Attribution Non Commercial (CC BY-NC 4.0) license, which permits others to distribute, remix, adapt, build upon this work non-commercially, and license their derivative works on different terms, provided the original work is properly cited, appropriate credit is given, any changes made indicated, and the use is non-commercial. See: http://creativecommons.org/licenses/by-nc/4.0/.

(c) Author(s) (or their employer(s)) 2020. Re-use permitted under CC BY-NC. No commercial re-use. See rights and permissions. Published by BMJ.

Fam Med Com Health 2020;8:e000406corr1. doi:10.1136/fmch-2020-000406corr1

(D) Check for updates 